\title{
Wisdom, friendship and the practice of philosophy
}

\author{
Beverley Clack, Oxford Brookes University
}

\section{Introduction}

In a recent article, Michael McGhee draws attention to the connection between personal experience and the themes pursued by the individual philosopher.1 Suggesting philosophy is never purely "objective" or "detached" is not new. Feminist scholars have long identified the importance of the personal for philosophical reflection. As Patricia Hill Collins notes, the theoretical and the practical are intimately connected in feminist politics. 2 This article develops that connection by considering friendship as a vital way of constructing philosophical practice as a means of enabling wisdom. It is also written as a response to the death of my friend and sometimes collaborator Pamela Sue Anderson in 2017.

Pamela and I met at a conference held towards the end of the 1990s. We had known of each other through our common interest in feminist philosophy of religion. Pamela was in the final stages of writing the book which was to become a landmark publication in this area.3 Common interests brought us together; her openness, warmth, and naughty sense of humour ensured we became friends. That friendship deepened through the time we spent together, through a miscarriage I suffered in 1999, and then, later, through the illness and death of her partner Paul. It was also framed by working together on a collection of essays in feminist philosophy of religion. 4 You learn a lot about someone when editing, and I remember fondly sitting together in the spring of 2003 as we put that volume together. As is common with a lot of friendships - particularly in the frenetic climate of the contemporary academy - we went through periods of seeing each other a lot, and then not that much. During the last months of her illness we renewed the depth of our friendship. Our last conversation inspired this paper, during which we talked about the potential of friendship to be transformative.

Pamela's last paper, given in absentia at a British Academy conference on vulnerability, finds her reflecting on the problem of being a woman in philosophy. 5 She highlights the isolation, the belittling of women's ideas, the problems of being a sometimes solitary female voice in a discipline dominated by men. Alongside these somewhat sad reflections is the call for solidarity between women, for this is one of the ways in which we can ensure the voices of women are heard. To show solidarity is to support each other; and this means taking practical steps to challenge those who would dismiss the things that women have to say. Feminist philosophy emerges as a grounded practice demanding solidarity.

The boldness of this last paper makes it a fitting conclusion to Pamela's philosophical work. Her philosophy steps out of the shadows to reveal aspects of her life, weaving the two intimately together. My article picks up on a theme implicit in Pamela's paper: friendship. How might the practices of friendship enable renewed thinking about what it is to be a philosopher in the twenty-first century? It is impossible to think about the practice of philosophy without considering the shape of the university that invariably provides the context for its practice. Philosophy is that part of the academy that should more than any 
other subject provide a space for the critical engagement with thought; but it also promises more than that, for it offers a space for thinking explicitly about how our thought enables the development of wisdom.

To talk of wisdom might seem old-fashioned. It is not necessarily the first word we think of when attending to the demands of the twenty-first-century university. The university has not escaped the trend of the last forty years in Western societies to view everything through the lens of the economic. Structured in response to neoliberal concerns with financialization, utility, and employability, the contemporary university is not necessarily amenable to ideas of what it is to be wise. This is particularly problematic for philosophy, given that wisdom is its central, organizing principle. Philosophers do many things, partake in many different fields, and focus on many different themes; yet informing these practices is the implicit assumption that something vital is performed when we think philosophically that reveals the nature of being human. To be human is to have the capacity to think seriously about life and how best to live. As Pamela puts it, philosophical practice revolves around this question: "Can one make sense of one's life while living it?" 6 In what follows, I suggest that shaping philosophical practice through the lens of friendship invites a reframing of the university as a place which enables the cultivation of wisdom: an idea sadly at odds with its current economic framing, but with the potential to revitalize both philosophical enquiry and the university.

\section{The problem of the neoliberal university}

It is tempting to consider the practices of philosophy as if they are unaffected by the political framing of the university as an institution. This will not do, for the form the university takes has considerable impact on the practice of the philosophy taught and researched within it, as I intend to show. In considering the pressures on philosophical practice arising from its placing in a specific political time and place, my comments emanate, necessarily, from the context of the United Kingdom; there is, however, likely to be considerable overlap with the practices of universities in other places, given that the agenda shaping UK universities is one transcending national boundaries. Recent commentators on the challenges facing universities include Stefan Collini,7 Martha Nussbaum, 8 and Bob Brecher.9 If Collini uses John Henry Newman as his conversation partner, the political philosopher Michael Oakeshott, writing in the 1950s, acts as a helpful interlocutor for the framing of my reflections when he sets out the problems facing the academy of his day:

The university will have ceased to exist when its learning has degenerated into what is now called research, when its teaching has become mere instruction and occupies the whole of an undergraduate's time, and when those who have come to be taught come, not in search of their intellectual fortune, but with a vitality so unroused or so exhausted that they wish only to be provided with a serviceable moral and intellectual outfit; when they come with no understanding of the manners of conversation but desire only a qualification wisdom, friendship and philosophy for earning a living or a certificate to let them in on the exploitation of the world.10 
Some seventy years on, this description fits rather too well with the experience of those teaching and researching in many (perhaps most) British universities. (Members of "elite" institutions may not recognize their experience in the words of this passage; this is unlikely, I think, given the role government frameworks have played in shaping the practice of all Higher Education institutions since the 1980s.11) In post-1992 universities, certainly, Oakeshott's fears reflect the situation all too accurately. Academics' work is fragmented into "research" and "teaching," with hours assigned to each as if they constitute discrete tasks. Students are encouraged to visualize their relationship to their tutors as that of customer to service provider: a model which is hardly surprising, given that the fees structure suggests they are indeed paying for the "services" of their tutors. The question of whether they are getting "value for money" inevitably arises. Is the student (or their parent) getting a good return on their financial investment? Will the student be able to achieve a well-paid "graduate" job? The implication of asking such questions is illustrated in reports in 2018 that Hull University was to close its Philosophy programme. We might expect recruitment to be the issue. This was not, however, the case: students wanted to study philosophy at Hull. When pressed to explain the university's proposal, Hull's registrar explained that the intention was "to ensure that [a student's] qualification holds value over time," as well as that the university "meets the needs of our students, research and business partners." 12 In other words, philosophy must go as its graduates are not the kind of workers required by today's businesses, and certainly not by those businesses where they are likely to make the most money.

This example suggests something of just how far reaching are the consequences of framing the university and what happens within it through the lens of the economic. We might well see in this example Oakeshott's fears about what happens to the university when it is understood solely as a means to an end. What is the function of an education? What is a university for?

Oakeshott focuses explicitly on that last question. Writing in the aftermath of the Second World War, and against the backdrop of a post-war Labour government anxious to shape a new, fairer society, he directs his attention to the problem of shaping of the university as a tool for achieving governmental goals. The ideals shaping this government's policies might seem benign, their aim to develop a more inclusive, socially just society. Yet Oakeshott is worried about the effect of prioritizing a set of political imperatives. The very idea of what constitutes "the university" is undermined by such an approach. His account of what makes for a university shows why he thinks this. The university is "not a machine for achieving a particular purpose or producing a particular result; it is a manner of human activity." 13

To define the university as "a manner of activity" is to understand the university as an ongoing conversation, a place for talking and thinking. It is a community bound together by a shared conversation. The aim of the university is thus to promote "the pursuit of learning as a cooperative exercise." 14 There is no end point to such a vision, no handy cut-off point for this ongoing conversation. The university is "not a machine" 15 committed to producing a uniform and clearly determined end. To even ask what the university is for is to fall prey to forces that would reduce all forms of value to questions of usefulness. To be part of a 
university is to be part of an ongoing conversation that cannot be so neatly circumscribed. For Oakeshott, this conversation has a particular form, for it involves dialogue with the historical texts that have shaped "our" culture.16 He is explicit as to the nature of the culture to which he refers. The university is concerned with explaining and communicating a set of specific historical texts that form the basis for a shared cultural life. The conclusion is, he claims, that the university is "unavoidably conservative."17

Here, the liberal academic, working in a multicultural context may well feel uncomfortable, for Oakeshott, presumably, will have no truck with ideas of broadening the canon, or challenging the whiteness or maleness of the curriculum. His university is a "conservative" institution. Before rejecting such an idea out of hand, however, it is worth thinking a little more about what exactly we might want to "conserve" when we consider the university. What happens if it is framed as an institution through "progressive" ideals? Oakeshott's contention is that it is the practices of the university that require conservation. Historically, the university has been shaped as a place for thinking and talking: no more, no less. Oakeshott's anxiety centres on what he sees as the politicizing of the academy. Viewed from the vantage point of 2019, the concerns of the 1945 Labour government with which Oakeshott takes issue may well be ones we wish to endorse. Attempting to create a more equal society out of the rubble of the Second World War, and thus to see the universities as important motors for social change, seems all very laudable. Yet what Oakeshott identifies are the problems that arise when the university is seen primarily from the perspective of governmental concerns to address wider social issues. Claims about its use - the ends to which it should be directed - come to define the work of the university, not its historical shaping as a place of ongoing conversation into which students are inducted.

If Oakeshott was bothered by the political shaping of the university of his day we have cause to be even more concerned by political interventions which would determine the function of a university education. Today's university is not even seen as an institution that can address entrenched social injustice. If it were, maintenance grants for the very poorest students would not have been scrapped in 2016, nor attempts at cultivating "lifelong learning" shunted to the sidelines. The university of our times is shaped by economic imperatives that see it as valuable only if it contributes to the work of wealth creation, or when its resources are directed to training the skilled workers required by business. There are dangers when defining a university education through its function, for invariably functional accounts force it to amend its core activities to whatever political ideas are in vogue at the time. These might be laudable, but, then again, they might not. Either way, they distort what the university should be.

To understand the politics which shapes the universities of our time, it is necessary to interrogate the dominant political and economic ideology of the last forty years: neoliberalism. If Enlightenment thinkers conceived the individual as rational, autonomous, free, capable of choice, the contemporary iteration of that account of the human subject locates the individual in an explicitly economic setting. Emerging in the late 1940s as a response to the perceived threat of the Keynesian State for individuals and for business, the ideas of this "new liberalism" came into their own as politicians sought new solutions to the 
political crises of the 1970s.18 The triumph of neoliberalism in the governments of Ronald Reagan in the United States and Margaret Thatcher in the United Kingdom involved instigating economic policies which would free up business through the cutting of red tape and the curbing of the public sector. But this was never just a political movement consisting of a set of discrete economic policies. More dramatically, the aim was "to maximise competition and competitiveness, and to allow the market to permeate all aspects of life." 19 This "financialisation of everything" 20 required areas previously located outside the scope of business and the market - health, education, social services - to be understood through the needs of business and the imperative to create economic growth. 21 As Wendy Brown notes, neoliberalism is not simply an economic policy but rather "a governing rationality that disseminates market values and metrics to every sphere of life." 22

"Every sphere of life" is to be subjected to a business ethos. "The Market" becomes a regulatory tool that transcends the messiness of human relationships. While human beings are subjective and open to bias, the Market is objective and neutral.23 Economic assessment becomes the principal criterion for assigning meaning, with right- and left-wing governments accepting this framing of reality. Not only are institutions to be viewed through an economic lens. The new economics requires a new kind of individual: one shaped as an economic unit, detached from community, capable of responding to the demands of a new, global, and connected world. The individual is a minibusiness, a human resource, an entrepreneurial subject,24 capable of shaping their own social, economic and political destiny. In a series of lectures given in the late 1970s, Michel Foucault provides a neat name for this new human being: "homo economicus" or "Economic Man". 25

Education is not immune from this extension of the economic. How do you ensure citizens have the right skills for successfully negotiating a world which demands flexible employment? As funding models changed, so universities could not escape engaging with this question. The university began to be modelled as if it were a business. Vice Chancellors took on the character of CEOs; self-governance gave way to managerialism. Targets were routinely set, and competition enshrined as the mechanism for determining where funding should go. Collini provides some key dates which enabled this shift in the nature of the university. The year 1981 saw savage cuts to university funding. In 1986, funding for research was tied to the first Research Assessment Exercise. The year 1988 saw changes to the legal status of academic tenure, with university funding now dependent on delivering reforms and meeting targets. In 1992, "new universities" were created out of the old polytechnics: in part to further "diversify" the kind of university education on offer to students. The expansion in student numbers seen during this period was, crucially, not accompanied by increased investment, with the result that the "unit cost" of Higher Education was driven down.26 Accompanying these structural changes was a shift in how the student was encouraged to view their experience. No longer shaped through studying a subject for its own sake, "being a student" now involved learning a set of skills through a subject that would enable them to become the adaptable worker needed by the broader economy. 
Being an academic in such a context also changed. "Quality Assurance" measures ensured that "learning outcomes" and "learning objectives" determined the end point of teaching. Attention to transferable skills shifted the gaze from the content of disciplines to the creation of "flexible" learners. Subject to the forces of competition, all academics could not but be aware of the external factors governing their research. Consider the effect of attaining a coveted $4 *$ rating in the regular "Research Excellence Framework" exercises. This grading never simply denotes the quality of one's work, but is required if one's institution is to attain the funding it needs. Fail to achieve the funding and there is a very real possibility that your department or subject area will close as economically unviable. It would be a mistake to see competition as completely alien to the academy. Literary representations of academics as solitary, arrogant, obsessed with attaining some treasure or besting some rival would not be so commonplace if they did not reflect to some degree the reality. If we return to Oakeshott, a rather different view of our relationship, one with the other, emerges: "The pursuit of learning is not a race in which the competitors jockey for the best place, it is not even an argument or a symposium; it is a conversation." 27

The apparently nebulous notion of a conversation might lead philosophers - already on the back foot under the imperative to see everything through the lens of the economic - to avoid this framing for justifications of their discipline. The "value" of philosophy might be attempted on economic grounds: its "transferable skills" of critical thought enable students to "think outside the box," a quality that comes from philosophical study and that businesses report liking.28 This approach may be pragmatic, but it implicitly accepts the claim that only in the economic is meaning to be found.

Stefan Collini provides an alternative approach which reflects Oakeshott's claim that conversation provides a more fitting model for the university. His advice is simple: resist offering reductionist economic answers to the meaning of the university by stating over and over the practices of academics and what it means to be educated. The university is "a protected space in which various forms of useful preparation for life are undertaken in a setting and manner which encourages students to understand the contingency of any packet of knowledge and its interrelations with other, different forms of knowledge."29

The university is a space that allows for preparation for life. Framing a subject like philosophy economically ignores this broader placing. Restating what education involves enables resistance to be made to the functionalist accounts misshaping it. Here, Oakeshott's model of conversation does more than suggest the place of philosophy in the life of the university. Modelled as a conversation, philosophical enquiry also looks rather different. "It has no predetermined course, we do not ask what it is 'for', and we do not judge its excellence by its conclusion; it has no conclusion, but is always put by for another day." 30 We might well return to the existential questions with which the philosopher was once intimately engaged: why are we born? Why do we love? Why do we suffer? Why do we die? How do we make sense of our existence? These are questions that can never be concluded, for they arise from human experience and thus always require fresh engagement.

Feminist philosopher Michele Le Doeuff suggests a similar vision of the philosopher as engaged in an open-ended conversation. To be a philosopher does not involve joining a 
particular school of thought; nor does one become a philosopher through finding a master to whom one could become a disciple. Rather, it is practising philosophy that makes one a philosopher.31 In thinking critically for one's self, something else happens. One's world is opened up as that which we take for granted is challenged.32 The Neoliberal University, by way of contrast, is framed by the desire to close down, to find that end point which the philosopher should resist. Philosophical practice modelled as conversation involves opening up one's engagement with life. It also suggests the significance of relationship for the practice of philosophy, for to converse requires someone with whom to speak. What happens if this model is pursued: for philosophy, but also for the university?

\section{Friendship and becoming wise}

Here, we must return to a discussion of the significance of relationship for philosophy, and particularly to consideration of the practices conducive to the development of wisdom. Pursuing this thread offers the possibility of challenging the functional and constrained model of intellectual enquiry dominating neoliberal universities. If we consider the meaning of "wisdom," we find that is not synonymous with the study of philosophy, for it goes beyond acquiring a particular set of facts, or even engaging in the clarification of ideas. To talk of wisdom is to describe a way of being in the world which emerges from deep reflection on the nature of things. If we reflect on the history of philosophy, a close connection can be discerned between epistemology and ethics. Critical thinking is viewed as enabling better understandings of the world, which themselves provide the basis for better living.33

Artistic representations of "the philosopher" resist suggestions that there is any one way of construing the relationship between thought and the practice of living. Notably, there is little agreement on the role that relationship might play in enabling the development of a wise perspective on life. Gerard van Honthorst's painting "The Steadfast Philosopher" (1623)34 portrays the philosopher, surrounded by "his" books, in the act of shunning the attentions of a scantily clad woman who is attempting to seduce him away from his studies. Relationship - or at least sexual intimacy - would seem to be at odds with the solitary work of philosophical reflection. Edward Hopper's "Excursion into Philosophy" (1959) may be painted some three hundred years later, yet it suggests that a similar detachment is necessary for the work of philosophical reflection.35 A man sits on a bed, a discarded book by his side. Behind him, a woman is lying on her side, her buttocks exposed to the viewer. The physical world, connected with Woman, is to be rejected in favour of reflection.

Both paintings reflect the problematic place of Woman in the history of Western philosophy. The male, associated with thought, mind and rationality, is defined in distinction to the supposed female characteristics of physicality, body and emotions.36 Philosophy, practised by the male, reflects this sense of detachment. But there are other ways of portraying philosophical work, ways which acknowledge the importance of conversation for reflection, and which make engagement with others absolutely necessary for the kind of philosophy that enables wiser ways of living in the world. 
An image suggesting an alternative mode of reflection is presented by Stanley Spencer in his "Consider the Lilies" (1939), one of the paintings in his series Christ in the Wilderness. 37 Given the title of this series, we might anticipate a similar idea to that of van Honthorst and Hopper. To be wise or to cultivate deep reflection involves entering the wilderness, detaching oneself from world and others. Christ's attitude in Spencer's painting could not be further from this claim. Surrounded by daisies, Christ is attending to these flowers with the entirety of his being. He's looking at them; he's thinking about them; he's really engaging with them. Pamela Sue Anderson described wisdom as "the thoughtful love of life," and in this picture that notion is expressed perfectly. A connection is made between Christ and the flowers to which he is attending. It is not difficult to see in his posture Anderson's definition of what this thoughtful love of life would involve: it would be "a love which is informed by thinking about life, perhaps about the biological, but even more about a way of life for relational subjects who in living generate a collectivity of thinkers." 38

That latter point suggests something of the intensity of attention. Rather than see it as dependent on isolation, Anderson suggests that it requires connection. A similar claim informs the perspective cultivated by the Ancient Hellenistic Schools. Philosophy is a critical discipline embedded in life.39 Connecting philosophical practice with life as it is lived is a perspective found in both the Epicurean and Stoic Schools. For Epicurus, wisdom requires avoiding empty argument or rhetorical flourishes. Taking his lead from Aristotle, and modelling philosophy as a form of medicine, its practice must be focused on relieving the anxiety and suffering that inevitably accompanies life in this world: "empty is that philosopher's argument by which no human suffering is therapeutically treated." 40 The Stoic Seneca offers a similar vision of philosophy: it is not the same as wisdom, but its practices are directed at this goal.41 Working at a correct understanding of the nature of the universe is important and, once this is attained, one must align one's actions with it. The concern of philosophy is, as a result, "not with words, but with facts." 42 But this is not the acquisition of facts for their own sake. A better understanding of the nature of things opens up better ways of living. Elaine Fantham's recent translation of Seneca's letters gets at this rather well: philosophy "does not consist of words but deeds." 43 If Seneca's critics have accused him of rather too great a love of words, 44 the point remains. Something more is required than the love of words if the philosopher is to help us live well.

An important aspect of this "something more" is friendship. To become a philosopher requires a kind of intimacy. Solitary philosophical practice is not by itself sufficient for the attainment of wisdom. The practices of the Ancient Schools reveal this most clearly. Epicurus' students gather around him in a place that sounds not dissimilar to a commune, for the pursuit of wisdom requires a life together. 45 Given the communal context of Epicurus' "Garden," it is not surprising that friendship should be viewed by Epicurus as vital for a deeper engagement with other and the world: "Of all the means which are procured by wisdom to ensure happiness throughout the whole life, by far the most important is the acquisition of friends." 46 The Stoics mirror something of the high value placed on friendship. It is a gift from God which allows for the exploration of the things necessary for the pursuit of wisdom.47 The role of dialogue and letters in Seneca's work suggests 
something of how it enables this. Philosophy is an intimate practice, something we do together, as the tone of his letters to his friend Lucilius suggests.

The high place given to friendship reflects the indebtedness of the schools to Aristotle. Here, perhaps, we get an indication of the problems arising when friendship is identified as vital for the development of wisdom. Aristotle, his ideas shaped by the rigid distinctions between class and sex in his society, makes the highest forms of friendship dependent on equality of status. $48 \mathrm{He}$ is not alone in this, and seems to be drawing on the ideas of his mentor Plato. Sure, wisdom is developed in the context of friendship, a perspective to which Plato draws attention in his Symposium. But the kind of friendship Plato has in mind requires a mature relationship of equals if it is to enable a shared exploration and contemplation of the Good.49 It is male companions of equal standing who are able to share ideas, who are "mentally pregnant," 50 and who are "filled with the offspring you might expect a mind to bear and produce."51 These mental offspring are immortal, not prey to death and decay in the way that physical children, created out of a man's love for a woman, are.52 Only a relationship of (male) equals makes possible the creation of philosophical ideas.

The philosophical schools which followed Aristotle were far more open, broadening out the conditions that make for such companionable relationships.53 Feminists, likewise, have explored the possibilities of friendship in ways that reconfigure the claims of Plato and Aristotle.54 Julie K. Ward, in particular, argues that Aristotle's writing on philia opens up possibilities for feminist accounts of female friendship.55 But before turning too quickly from the limitations of their constructions, it must be acknowledged that Aristotle and Plato highlight the difficulty of placing personal connection at the heart of philosophical practice. If friendship enables the kind of philosophical practice vital for the goal of attaining wisdom, isn't this to ground it in a practice that by its very nature is exclusive? Friendships inevitably emerge from common experiences that necessarily exclude others. Before addressing the problems of friendship, let us say something about its transformative possibilities, for it is these virtues that make grappling with its problems worthwhile. While pursuing friendship suggests grounding philosophical practice in relationship, it also suggests a vision of the university that could not be further from the economic concerns which currently shape it.

\section{The model of friendship for philosophical practice}

Rather than think of philosophy as thought-inisolation, making friendship the context for its practice allows something more intimate and personal to emerge. In the experience of friendship, the other person is met, and in that meeting an openness develops to life in all its varied hues and tones. The philosophical practice which emerges from friendship is first and foremost personal. "Lived experience" is not something to be ashamed of, nor is it to be factored out of our discussions. There need be no separation between one's life and one's philosophical pursuits. If anything, the experiences of life lend themselves to the philosophical questions to be pursued. So Michele Le Doeuff relates her experience of sexism in French schooling to a broader discussion of the historic and continuing problems women face in being taken seriously as scholars.56 Likewise, Lawrence Hatab links his careful scholarly work on Nietzsche's eternal recurrence with the sense of relief he felt when encountering Nietzsche's writings for the first time. Confronted with a philosopher 
who battled physical and mental illness in life and in his work, Hatab felt less alone, finding in Nietzsche's struggles with mental and physical illness something of his own sense of alienation from life. Rather than see this felt connection as something to be overcome by an appropriate philosophical detachment, he makes this intimacy central to his analysis of Nietzsche's writing: "I think I can say that I know Nietzsche's sentences 'by heart.'”57

Acknowledging the personal well-spring for enquiry returns us to the existential questions once deemed central to philosophical enquiry. The practice of philosophy encompasses not just the preoccupations of the trained philosopher but also the experiences of all human beings. "Why was I born?" "What is it to love?" "What does death mean?" "Why do we suffer?" As we journey through life with our friends we are likely to find our conversations including these questions as we encounter the visceral human experiences which give rise to them. A philosophy framed in response might be less technical, more connected to the desires and fears of those outside the academy. Questioning, critical thought meets the ordinary experience of being human.

Existential questions require serious engagement. This is about more than clever argument: it is about how we are to live. The experiences that give rise to them propel us - often against our will - into a deeper engagement with life in this world. As Paul Tillich notes, "there can be no depth without the way to depth."58 The encounter with failure, loss, suffering, and grief acts as a provocation to go beneath superficial understandings of ourselves and the world. These are the times when we are "questioned by life,"59 to use Holocaust survivor and logotherapist Viktor Frankl's reformulation of what happens when we are confronted with suffering. This is about more than an abstract philosophical problem. As mutable beings, we cannot escape this questioning. But rather than be swamped by events we can reflect upon them, interrogate them, explore them. It is no surprise to find philosophical preoccupations mirroring personal experience and, often, those things which are most troubling and upsetting.

The jewel at the heart of a philosophy modelled through friendship is that such painful themes need never be explored alone. Sara Maitland is quite right to resist the intrusion of noise into all aspects of life.60 This noisy world leaves precious little time for the solitude necessary for a proper engagement with one's place in the world. Philosophical enquiry requires space for quiet reflection; but as relational beings we also require the space to talk with others, to share thoughts, to refine ideas and to change them as the other person is encountered.

This is the power of friendship. A friendship of sufficient duration is likely to encounter joy, laughter and the delight of maturity; but also, inevitably, depression, disappointment, failure, and loss. As Pamela Sue Anderson develops her feminist philosophy of religion, she is at pains to note that it is not enough for the feminist to focus on life, for "we are given a life, but each of us also dies." 61 This is the inescapable reality that frames existence. The deepest friendships reflect this, for they are never framed just by an ability to share good times. Confronted by the pains of existence, it is then that there is the possibility of deepening the relationship through the sharing of such experiences. 
While this makes sense in the realm of friendship, we might wonder how this would shape the experience of the philosopher in the contemporary academy. Maggie Berg and Barbara Seeber provide a helpful account of its potential in their challenge to the culture of speed in the academy.62 Against the backdrop of an academy shaped by process, where "downtime" is seen as inefficiency, and where achieving targets limits the time that can be spent thinking in depth about anything, Berg and Seeber reflect on their experience of collaboration. Working together offers the possibility of resisting a view of education defined by the lauding of competition that accompanies marketization. It is a subversive form of activity. Reflecting on the experience of collaborative writing led Berg and Seeber to more than just the production of a co-authored text. In the process of writing, their friendship was deepened. This happened particularly in moments when they felt daunted by the task of writing together. Confessing to each other how inadequate they felt to the task, talking about their fears of failure, had a surprising result. Their work improved. It was not just that these moments of vulnerability acted as epiphanies for deeper relationship; they also allowed for the creation of better ideas, cocreated in their conversations.

"Collaboration is about thinking together"; 63 it is a form of intimacy.

Thinking together in the way Berg and Seeber describe suggests a different form of practice from the mechanisms that would enshrine objectivity in the assessment of academic work. There is a significant difference between the reflections of the "anonymous reviewer" of the peer review and the interventions of a friend:

When one of us considered an idea or sentence as not working, she was able to say so without crushing the other in the way that peer review often does. The underlying trust and respect made it possible to have an open exchange of ideas: we listened to each other in an attempt to understand rather than to find the weaknesses we had been trained to do. The result was the same.64

Trust, respect and the willingness to listen did not lead to sloppy thinking: quite the contrary. Collaboration led to better reflections and clearer expression.

Before we adopt too-rosy a view of this kind of working, we should return to the problems of modelling philosophy on friendship and personal connection which were identified in Plato's and Aristotle's models of friendship. There, the kind of friendship crucial to the developing of ideas was seen as possible only between equals. There is a truth here, for our friends are likely to be self-selecting, reflecting common occupations, based in common neighbourhoods or leisure activities or past histories. There is, then, a danger for a philosophy based on the practices of friendship. Feeling comfortable with a group of likeminded peers can alltoo-easily erode the place for critical enquiry. Our subjects and our reflections extend only to the desires and preoccupations of one particular group of people like us. Against the backdrop of university structures, it is easy to identify philosophy departments where few perspectives are offered outside those of the white, the male, and the middle class. 65

If philosophical conversation is not to be limited and narrow, the voices of groups excluded from it must be actively encouraged into the academy. Here, my conversation with 
Oakeshott enters difficult waters, for his account of the university explicitly rejects the intervention of government in higher education, and so would resist policies aimed at widening participation. There is, however, no easy fix to the limited nature of much academic conversation. Even if policies were in place to address the problems of cronyism and implicit bias, identified most recently by Jennifer Saul,66 there may still be good grounds for feeling uneasy about placing relationship at the heart of our philosophical practice. Friendships are not immune from the distortions of power, envy, and betrayal. They do not always make us more resilient, but can make us more vulnerable. Michele Le Doeuff 's analysis of the famous conversation between Jean-Paul Sartre and Simone de Beauvoir in the Luxembourg Gardens reveals a more disturbing side of intimacy. Beauvoir recounts this sad meeting in her Memoirs of a Dutiful Daughter. "Day after day" she measured herself against Sartre. Friends and companions, she excitedly shares with Sartre her nascent philosophy. He listens; and then "rips it to shreds." Crushed, Beauvoir decides that she is not a philosopher. Ever after she would say that she "left the philosophy to Sartre."67

Beauvoir and Sartre may be friends and collaborators; but that does not stop Sartre enacting the kind of intellectual bullying common in the academy. The very fact of their friendship probably makes Beauvoir more inclined to accept his conclusions about her work. Yet there is something in acknowledging the personal and its potential for a deeper kind of philosophical enquiry that makes me loath to give it up, even in the face of such an upsetting example of the limits of friendship.

\section{Friendship, risk and the neoliberal university}

Given the complexity, even the messiness, of friendship, it might seem easier to retreat into the more comfortable territory of the solitary philosopher, a formulation that also sits rather well with neoliberal accounts of the atomized subject. The scholar as individual rather than collaborator becomes a unit whose research can be graded, whose engagement with the subject can be defined according to "its" outcomes. Yet the vulnerability of friendship suggests something of why it might be particularly important when constructing an ideal for academic enquiry.

The cultural critic Marshall McLuhan describes the difficulty of seeing - really seeing - the cultural ideals and practices that surround us. We take our "environment" for granted, much as we take for granted the air that we breathe.68 Academics have become used to framing the university through neoliberal values. The language of economics, metrics and targets permeates every aspect of the twenty-first-century university. To recalibrate academic enquiry through the lens of friendship challenges the resulting complacency, acting as a reminder that institutions are not natural phenomena that cannot be framed in any other way. Institutions result from human decision making. The functionalism of the contemporary university is not a fact of life; it can be disrupted, and emphasizing the importance of relationship for the shaping of wisdom can go some way to enabling this change in perspective. 
Consider the fears that make the uncertainty of human relationships something requiring management. Hannah Arendt's critique of bureaucracy identifies this preoccupation. Bureaucratic systems reflect desires to contain and control that which is experienced as unpredictable and uncontrollable. Systems and processes attempt to manage the uncertainty of human relationships. But something vital is lost in the attempt to make safe that which can never be rendered certain. What is lost is the "startling unexpectedness"69 of human creativity. As spontaneous creatures it is always possible for human beings to "begin something new out of their own resources."70

Spontaneity brings with it risk. To allow for the spontaneous, to make room for the unpredictable, requires giving up ideas that the end of any particular endeavour is predictable or assured. When we act, we always do so in relation to others, and the way in which others respond is not something that can be circumscribed.71 This might make us uneasy, and it can seem preferable to apply models of production derived from the factory to all areas of human life and activity. The apparent certainty of this way of proceeding goes some way to explain the tenacity of neoliberal forms: they offer a comforting simplicity to the shaping of experience. Faith shifts from what happens between human individuals to the pleasing objectivity and cleanness of numbers. Financial models, metrics and statistics "come to take political precedence over the aesthetic, the affective and the hermeneutic."72 All can be contained through assigning discrete numbers or clear lists of outcomes.

Something is lost when faith in the system defines the activities of our institutions. For Arendt, what is lost is the possibility of spontaneous action; for me, it is the proper acknowledgement of the role that relationship plays in the flourishing human life. The personal opposes the supposed objectivity of the economic.73 Yet promoting the complexity and messiness of relationship can seem illadvised. We deceive ourselves, however, if we think adherence to "the System" will ensure the end of abuse or prejudice or unkindness. Risk remains an issue for the university, despite the application of such managerial tools. Far from eradicating unhappiness and vulnerability, the Economic University creates stress, unhappiness, and the conditions for bullying. The suicide of the biologist Stefan Grimm in 2014 is a case in point. Subjected to strict performance management systems, his death exposed the unbearable pressures staff were under in a target-driven university.74 Placing the System above the relational does not ensure the university as a place for flourishing.

Anxiety about possible abuses dogs pedagogical perspectives that would make relationship a vital aspect of teaching. Paul Tillich's writing is inspiring; but he has been exposed for having inappropriate relationships with his students and their partners.75 No university should turn a blind eye to abuses in the name of relationship, but to factor out the role of the relational in learning is to lose some of the most profound moments that happen incidentally, in an after-class discussion, or in an activity not obviously connected to the class materials. Good teaching never just involves the transferring of material from teacher to taught; it also involves "being interested in the pupil himself, in what he is thinking, in the 
quality of his mind, in his immortal soul, and not in what sort of school master or administrator he can be made into."76

This comment from Oakeshott raises, again, the importance of the open conversation. The limits of our own perspective are acknowledged; we listen to what the other has to say. The other is met as a person, not just as a fellow worker or someone who sits in a class. We talk with someone who may not share our views. To meet the other as a fellow human being requires honesty, and the ability to have our positions challenged. To listen is thus as important as it is to talk. In attentive listening we hear the other person into speech: an image that is a central ideal for feminist theological engagement.77

Embracing the risk of the personal requires two concepts that emerge from Arendt's account of the human condition: promising and forgiveness. In the promise, we attempt to provide some security for the other.78 Promises are serious because they attempt a degree of certainty in the realm of human relationships: I will behave in the way I tell you I am going to behave. The possibility of forgiveness is a necessary correlate to the promise, for it holds out the prospect of a future if actions are bad or go wrong.79 Forgiveness is not easy to give or to receive, and its difficulty acts as a reminder of the painful realities of a world where human beings are not perfect but are forged through the pain, as well as the joy, of lived relationship. How much richer our lives if we pay attention to these things which frame our experience, and which provide the basis for the kind of maturity necessary if a wiser perspective on life is to be cultivated.

\section{Conclusion: beyond the neoliberal university}

Paying attention to the role of friendship in the practice of philosophy suggests a vision of the subject that does not disconnect it from the totality of life, nor from the practice of living. Here is philosophy as the practice that enables wisdom, as it offers a space for grappling with the experiences of life and finding ways of coming to terms with them. It is difficult to see how the university as it is currently structured can provide the kind of space conducive for such practices. Yet exposing the paucity of its vision of education might go some way to demanding new visions of what might happen if the university returned to its historical place as a community engaged in collaborative thinking. We might note that, despite the last forty years of prioritizing the economic, the vision of the university as a community has not entirely been expunged. In January 2018 the University of London was the focus for a campaign aimed at ending the outsourcing of services such as catering and cleaning. Behind this action was the vision of the university as a community, where the work of all its members is vital for creating a setting where we flourish together through the practices in which we engage. When UCU took strike action to protect staff pensions, the union similarly refused to make its campaign just about the concerns of one group of workers. Instead, it also highlighted the pernicious effects of short-term or zero-hours contracts on the lives of younger academics. In both actions, students were overwhelmingly supportive of staff, and a new image of what the university could be is starting to emerge from the acknowledgement that something is lost when the university as a community is lost. 
Placing the human at the heart of our endeavours acts as a reminder of the vulnerability of our humanity. When I reflect on my friendship with Pamela Sue Anderson I cannot forget the fragility of the conversations we had. They were passing, just as we are passing. Perhaps it is that very fragility that contributes to the longing to formalize, to set in stone, to reduce to words on a page. Sure, I can look at the printed words we framed together; I can conjure up her presence as I read her articles and books. Yet it is the traces of the conversations we shared that live most: walking through University Parks during a solar eclipse, gossiping and laughing over drinks in Oxford pubs too numerous to name. In these memories, I find her presence as she heard me into speech. These remembered traces of our friendship continue to inspire me: delicate as flowers, ephemeral as mist. It is a difficult thing to come to terms with our transience as human beings. At its best, philosophy makes space for us to grapple with these realities. Here is where the possibility of wisdom is found. At its best, the university can provide a space for engaging with the deeper possibilities open to human beings which transcend cultural obsessions with work or money. Here is where the practice of philosophy finds its importance, for it offers a space for meeting each other as real human beings, caught in the joys and sorrows of life. We are not economic units, we are creatures seeking to make sense of our lives, striving to find ways of living well together. In our practices as philosophers we can model these attempts, and in embracing the notion of an open-ended conversation we might even be able to create a university prepared to value what cannot be defined, what is difficult to capture, and what emerges from the fragility of being human.

\section{Notes}

1 Michael McGhee, "The Voice of Cordelian Ethics: Imagination and the Loss of Religion," Journal of Scottish Studies 10 (2018): 52-68.

2 Patricia Hill Collins, Black Feminist Thought (London: Routledge, 1991) xii.

3 Pamela Sue Anderson, A Feminist Philosophy of Religion (Oxford: Blackwell, 1998).

4 Pamela Sue Anderson and Beverley Clack, eds., Feminist Philosophy of Religion: Critical Readings (London: Routledge, 2004).

5 "Vulnerability and the Politics of Care" conference, British Academy, 9-10 February 2017. Pamela Sue Anderson, "Silencing and Speaker Vulnerability: Undoing an Oppressive Form of (Wilful) Ignorance," ed. Nick Bunnin, in Love and Vulnerability: Thinking with Pamela Sue Anderson, ed. Pelagia Goulimari, Spec. issue of Angelaki: Journal of the Theoretical Humanities 25.1-2 (2020): 000-000 [X-ref].

6 Pamela Sue Anderson, "'A Thoughtful Love of Life': A Spiritual Turn in Philosophy of Religion," Svensk Teologisk Kvartalskrift 85 (2009): 119-29 (119).

7 Stefan Collini, What Are Universities For? (London: Penguin, 2012).

8 Martha Nussbaum, Not for Profit: Why Democracy Needs the Humanities (Princeton: Princeton UP, 2010). 
9 Bob Brecher, "Universities: The Neoliberal Agenda" in Interrogating the Neoliberal Lifecycle: The Limits of Success, eds. Beverley Clack and Michele Paule (London: Palgrave Macmillan, 2019) 127-42.

10 Michael Oakeshott, "The Idea of the University" in The Voice of Liberal Learning, ed. Timothy Fuller (Indianapolis: Liberty Fund, 2001) 117.

11 Collini, What Are Universities For? [Kindle ed.] 32-38.

12 Julian Baggini, "If Universities Sacrifice Philosophy on the Altar of Profit, What's Next?," The Guardian 21 Dec. 2018, available <https://www.theguardian.com/commentisfree/2018/dec/21/universities-philosophyprofit-business-partners> (accessed 12 Feb. 2019).

13 Oakeshott, "The Idea of the University" 106; my emphasis.

14 Ibid. 107.

15 Ibid. 106.

16 Ibid. 116.

17 Ibid.

18 David Harvey, A Brief History of Neoliberalism (Oxford: Oxford UP, 2005) 1-38; Philip Mirowski, Never Let a Serious Crisis Go to Waste: How Neoliberalism Survived the Financial Meltdown (London: Verso, 2014) 27-88.

19 Guy Standing, The Precariat: The New Dangerous Class (London: Bloomsbury, 2011) 1. 20 Wendy Brown, Undoing the Demos: Neoliberalism's Stealth Revolution (New York: Zone, 2015) 28.

21 William Davies, The Limits of Neoliberalism: Authority, Sovereignty and the Logic of Competition (London: Sage, 2014) 20-23.

22 Brown, Undoing the Demos 176.

23 Davies, The Limits of Neoliberalism 22.

24 Thomas Lemke, "'The Birth of Bio-politics': Michel Foucault's Lecture at the Collège deFrance on Neo-liberal Governmentality," Economy and Society 30.2 (2001): 190-207 (199).

25 Michel Foucault, The Birth of Biopolitics, ed. Michel Senellart; trans. Graham Burchell (London: Palgrave Macmillan, 2008) 268.

26 Collini, What Are Universities For? 33-34.

27 Oakeshott, "The Idea of the University" 109; my emphasis.

28 Jessica Shepherd, "I Think, Therefore I Earn," The Guardian 20 Nov. 2007, available $<$ https://www.theguardian.com/education/2007/nov/20/choosingadegree.highereducation 
> (accessed 12 Feb. 2019); "What Can You Do with a Philosophy Degree?," Times Higher Education Supplement 17 Nov. 2016, available $<$ https://www.timeshighereducation.com/student/subjects/what-can-you-do-philosophydegree> (accessed 12 Feb. 2019); Nicholas Miller, "5 Reasons Why Philosophy Majors Make Great Entrepreneurs," Entrepreneur 5 July 2017, available <https://www.entrepreneur.com/article/295699> (accessed 27 Nov. 2019).

29 Collini, What Are Universities For? 56; my emphasis.

30 Oakeshott, "The Idea of the University" 109-10.

31 Michèle Le Doeuff, Hipparchia's Choice: An Essay Concerning Women, Philosophy, Etc. [1989], trans. Trista Selous (New York: Columbia UP, 2007) 59-60.

32 Michèle Le Doeuff, The Sex of Knowing, trans. Kathryn Hamer (London: Routledge, 2003).

33 Thus Lucretius' De Rerum Natura ("On the Nature of Things") is both a discourse on thenature of the universe and a reflection on how to live well in that world.

34

<https://commons.wikimedia.org/wiki/File:The_Steadfast_Philosopher,_by_Gerard_van_Ho ndhorst.jpg> (accessed 8 Feb. 2019).

35 <http://www.edward-hopper.org/excursioninto-philosophy/> (accessed 8 Feb. 2019).

36 Genevieve Lloyd, The "Man” of Reason (London: Methuen, 1984); Beverley Clack, "Introduction," Misogyny in the Western Philosophical Tradition: A Reader (London: Macmillan, 1999).

37 Mark Oakley's article "Invitation to Contemplate" in The Church Times 1 Feb. 2013 includes a reproduction of this painting and a helpful commentary on the contemplative function of the series of paintings of which it is a part. See $<$ https://www.churchtimes.co.uk/articles/

2013/1-february/books-arts/reading-groups/invitation-to-contemplate> (accessed 28 May 2019).

38 Anderson, "'Thoughtful Love of Life'” 120.

39 Pierre Hadot, Philosophy as a Way of Life, ed. Arnold I. Davidson; trans. Michael Chase(Oxford: Blackwell, 1995).

40 Quoted in Martha Nussbaum, The Therapy of Desire (Princeton: Princeton UP, 1994) 13; see also 121.

41 Seneca, Moral Letters to Lucilius, LXXXIX, "On the Parts of Philosophy" line 6, available $<$ https://en.wikisource.org/wiki/Moral_letters_to_Lucilius/Letter_89> (accessed 15 Feb. 2019).

42 Seneca, Letters from a Stoic, trans. Robin Campbell (London: Penguin, 1969) 64.

43 Seneca, Selected Letters, trans. Elaine Fantham (Oxford: Oxford UP, 2010) 31. 
44 F.H. Sandbach, The Stoics (Indianapolis: Hackett, 1994) 162.

45 Nussbaum, Therapy of Desire 119-20.

46 Epicurus, "Principal Doctrines," trans. P.E. Matheson, in Greek and Roman Philosophy after Aristotle, ed. Jason Saunders (New York: Free, 1966) 53-57, 55-56.

47 Seneca, "On Favours" in Moral and Political Essays, ed. and trans. John Cooper and J.F. Procopé (Cambridge: Cambridge UP, 1995) 288.

48 Aristotle, Nicomachean Ethics 8-9; Politics 1.13 on women; also Nussbaum, Therapy of Desire 54-56.

49 Plato, Symposium 209b.

50 Ibid. 209a, trans. Robin Waterfield (Oxford: Oxford UP) 52.

51 Ibid. 209a, 52.

52 lbid. 209c-d.

53 Epicurus was the first to open his school to women: Nussbaum, Therapy of Desire 117. Nussbaum also sees Lucretius as framing his ideal of marriage as a form of philia: ibid. 187.

54 For a variety of explorations of friendship, see, for example, Marilyn Friedman, What Are Friends For? (Ithaca, NY: Cornell UP, 1993); Mary Hunt, Fierce Tenderness: A Feminist Theology of Friendship (New York: Crossroad, 1991); Melissa Raphael, The Female Face of God in Auschwitz (London: Routledge, 2002).

55 Julie K. Ward, "Aristotle on Philia: The Beginning of a Feminist Ideal of Friendship?," Feminism and Ancient Philosophy, ed. Julie K. Ward (London: Routledge, 1996) 155-71. 56 Le Doeuff, Hipparchia's Choice.

57 Lawrence Hatab, Nietzsche's Life Sentence: Coming to Terms with Eternal Recurrence (London: Routledge, 2005), esp. 111-13 (113).

58 Paul Tillich, The Shaking of the Foundations [1949] (Harmondsworth: Penguin, 1962) 61. 59 Viktor Frankl, Man's Search for Meaning, trans. Ilse Lasch (London: Rider, 2004) 12. 60 Sara Maitland, A Book of Silence (London: Granta, 2010.)

61 Pamela Sue Anderson, "Life, Death and (Inter)-subjectivity: Realism and Recognition in Continental Feminism," International Journal for Philosophy of Religion 60.1 (2006): 41-59 (41).

62 Maggie Berg and Barbara Seeber, The Slow Professor (Buffalo: U of Toronto P, 2016). 63 Ibid. 89.

64 Ibid. 88; my emphasis. 
65 For critiques of academic cronyism, see bell hooks, Where We Stand: Class Matters (London: Routledge, 2004); Patricia Hill Collins, Black Feminist Thought (London: Routledge, 1990).

66 Jennifer Saul, "Implicit Bias, Stereotype Threat, and Women in Philosophy," Women in Philosophy: What Needs to Change?, eds. Katrina Hutchison and Fiona Jenkins (Oxford: Oxford UP, 2013) 39-60.

67 Le Doeuff, Hipparchia's Choice 136.

68 Marshall McLuhan, The Relation of Environment to Anti-Environment (Berkeley: Gingko, 2005).

69 Hannah Arendt, The Human Condition [1958] (Chicago: U of Chicago P, 1998) 178.

70 Hannah Arendt, The Origins of Totalitarianism [1948] (New York: Harcourt, 1968) 455.

71 Arendt, Human Condition 182-84.

72 Roger Burrows, "Living with the H-Index? Metric Assemblages in the Contemporary Academy," Sociological Review 60.2 (2012): 355-72 (358).

73 For problems with the supposed objectivity of statistics, see lan Hacking, The Taming of Chance (Cambridge: Cambridge UP, 1990).

74 Chris Parr, "Imperial College Professor Stefan Grimm 'Was Given Grant Income Target,'” Times Higher Education Supplement 3 Dec. 2014, available

$<$ https://www.timeshighereducation.com/news/imperial-college-professor-stefan-grimmwas-givengrant-income-target/2017369.article> (accessed 25 Feb. 2019).

75 Hannah Tillich, From Time to Time (New York: Stein, 1973).

76 Oakeshott, "The Idea of the University" 113.

77 See Catherine Keller, "The Apophasis of Gender: A Fourfold Unsaying of Feminist Theology," Journal of the American Academy of Religion 76.4 (2008) 905-33.

78 Arendt, Human Condition 243-47.

79 Ibid. 237. 